\title{
COVID-19 and Rheumatic Diseases
}

\author{
Gezmiş KİMYON ${ }^{\mathbf{1}}$ \\ (D) 0000-0003-3775-639X \\ Taşkın DUMAN ${ }^{2}$ \\ (D) 0000-0002-6552-4193
}

\author{
COVID-19 ve Romatizmal Hastalıklar
}

\begin{abstract}
Severe acute respiratory syndrome coronavirus 2 (SARS-CoV-2) is an infectious agent affecting respiratory system the most and spreads rapidly due to large number of ACE2 receptors in the lung. Arthralgia and myalgia are the most common rheumatologic findings, but arthritis is rare. Hyperinflammatory condition called cytokine storm causes acute respiratory distress syndrome (ARDS) leading to death. Although coronavirus disease 2019 (COVID-19) is mild or asymptomatic in most cases, it may progress to pneumonia and ARDS, especially in elderly patients who have comorbidities. Drugs such as tocilizumab which suppress inflammatory response and reduce cytokine storm may be effective on treating COVID-19 pneumonia. Cytokine storm, the cause of which is not fully understood and in which many structures of immune system interact with each other, is quite complex and has different mechanisms contributing to it. Although antimalarial drugs such as hydroxychloroquine are used in the treatment, there is no definite evidence that they are effective. It has been shown that the prevalence and course of COVID-19 in rheumatic diseases is similar to the general population, and that increasing age and additional comorbid conditions of rheumatic diseases should not be stopped unless the patient is infected with COVID-19. Keywords: COVID-19; rheumatic diseases; cytokine storm; anti-rheumatic drugs.
\end{abstract}

${ }^{1}$ Mustafa Kemal University Faculty of increase the risk of mortality. It is recommended that anti-rheumatic drugs used in the treatment Medicine Department of Rheumatology, Hatay, Turkey

${ }^{2}$ Mustafa Kemal University Faculty of Medicine Department of Neurology, Hatay, Turkey

\section{Corresponding Author Sorumlu Yazar Gezmiş KIMMYON gkimyon@gmail.com}

Received / Geliş Tarihi : 31.08.2020 Accepted / Kabul Tarihi : 18.10.2020 Available Online /

Çevrimiçi Yayın Tarihi : 25.11.2020

\section{ÖZ}

Şiddetli akut solunum yolu sendromu koronavirüsü 2 (severe acute respiratory syndrome coronavirus 2, SARS-CoV-2) solunum sistemini en çok etkileyen ve akciğerdeki çok sayıda ACE2 reseptörü nedeniyle hızla yayılan bulaşıcı bir ajandır. Artralji ve miyalji en sık görülen romatolojik bulgulardır, ancak artrit nadirdir. Sitokin firtınası adı verilen hiperinflamatuar durum, akut solunum sikintısı sendromu (acute respiratory distress syndrome, ARDS)'na neden olarak ölüme neden olur. Koronavirüs hastalı̆̆ 2019 (coronavirus disease 2019, COVID-19) çoğu durumda hafif veya asemptomatik olmasına rağmen, özellikle ileri yaş ve komorbiditeleri olan hastalarda pnömoni ve ARDS'ye ilerleyebilir. Enflamatuar yanıtı baskılayan ve sitokin firtınasını azaltan tosiluzumab gibi ilaçlar, COVID-19 pnömonisinin tedavisinde etkili olabilir. Nedeni tam olarak anlaşılamayan ve bağışıklık sistemindeki birçok yapının birbiriyle etkileşime girdiği sitokin firtınası oldukça karmaşıktır ve buna katkıda bulunan farklı mekanizmalara sahiptir. Tedavide hidroksiklorokin gibi antimalaryal ilaçlar kullanılsa da etkili olduklarına dair kesin bir kanıt yoktur. Romatizmal hastalıklarda COVID-19 sıklığının ve seyrinin genel popülasyona benzer olduğu, artan yaş ve ek komorbid durumların mortalite riskini artırdığı gösterilmiştir. Romatizmal hastalıkların tedavisinde kullanılan anti-romatizmal ilaçların, hasta COVID-19 ile enfekte olmadıkça kesilmemesi önerilmektedir.

Anahtar kelimeler: COVID-19; romatizmal hastalıklar; sitokin firtınası; anti-romatizmal ilaçlar. 


\section{INTRODUCTION}

Severe acute respiratory syndrome coronavirus 2 (SARS-CoV-2) is an infection agent from the coronavirus family that started in Wuhan, China in December 2019 and spread to the world, causing a pandemic. The coronavirus disease 2019 (COVID-19) classically affects the respiratory tract and can spread very quickly because of its highly contagious nature. The most important cause of mortality in patients is complications such as acute respiratory distress syndrome (ARDS), which occurs after severe pneumonia. Although symptoms such as fever, cough, and dyspnea are the most common findings, they can be seen in findings related to arthralgia and myalgia in the musculoskeletal system $(1,2)$.

It has been reported that comorbid conditions such as increasing age, male gender and hypertension increase the risk of mortality in COVID-19 (3). On the other hand, inflammatory rheumatic diseases are common in the public and it is known that both rheumatic disease itself and steroid and other immunosuppressive drugs used in treatment can increase the risk of infection by suppressing the immune system. This can reduce the compliance of drugs used in the treatment of primary rheumatic disease in people with rheumatic disease during the COVID-19 pandemic process. Recent findings indicate that the risk of COVID-19 is the same in people with and without rheumatic disease of similar age and gender. However, this situation may cause serious anxiety in those with rheumatic disease (4). Institutions such as European League Against Rheumatism (EULAR) and the European Rheumatology Association have published algorithms on the treatment and management of rheumatic diseases during the COVID-19 pandemic with their temporary recommendations (5).

Another issue is the use of some drugs used in the treatment of rheumatic diseases in the treatment of COVID-19. It has been suggested that these drugs, particularly chloroquine (CQ) and hydroxychloroquine (HCQ), can be effective in the treatment of COVID-19 infection and has entered treatment algorithms. Discussions about the use of these drugs in COVID-19 will continue until new findings are obtained in controlled studies in the coming period (6). Another interesting issue is the hyperinflammatory condition known as cytokine fever, which is more common in Juvenile Idiopathic Arthritis and Adult Still disease in rheumatology practice, but is known to be made by many infectious agents. It is thought that anti-cytokine treatments targeting cytokines such as IL-1 and IL- 6 are used in the treatment of some rheumatic diseases and cytokine storm, which is an important cause of death, with ARDS and multi-organ failure caused by COVID-19 (7). In this article, the aspects of COVID-19 overlapping with rheumatic diseases, cytokine storm, frequency in rheumatic diseases, and the relationship between drugs used in the treatment of rheumatic diseases and COVID-19 will be discussed.

\section{Prevalence of COVID-19 in Inflammatory Rheumatic Patients}

The COVID-19 pandemic, which started in December 2019 in China and spread all over the world with its fast contagiousness, still affected a small part of the world proportionally in the summer of 2020 . Considering that most of the population does not encounter this infection, concerns remain due to the negative clinical picture that it will create especially in risky disease groups. There are various immune system related problems in inflammatory rheumatic diseases, and especially immunosuppressive drugs used in treatment may increase the risk of infection. However, in the first published data, the prevalence of COVID-19 in inflammatory rheumatic patients was shown to be similar to the population (8). In a study conducted in Spain, it was shown that the risk may vary according to the disease subgroups. In this study, while patients with rheumatoid arthritis (RA) and psoriatic arthritis (PsA) had a similar risk to the community, the risk was higher for the patients with spondyloarthritis ( $\mathrm{SpA}$ ), especially those using targeted synthetic disease modifying drug (tsDMARD) and biological disease modifying drug (bDMARD). In systemic lupus erythematosus (SLE), it was found to be similar to the population (9). In another study from Spain, the risk of COVID-19 was found similar to the general population, even in adult and pediatric patients with rheumatic disease even if they use tsDMARD (10). In a study conducted in Italy, the prevalence of COVID-19 was found at a rate similar to the general population in chronic inflammatory rheumatic patients (11).

\section{Rheumatic Findings of COVID-19}

COVID-19 is most often manifested by symptoms related to the respiratory system, such as cough, sore throat, dyspnea, along with fever. Although these are common symptoms, many system related findings have been associated with COVID-19. In the musculoskeletal system, it often causes myalgia and arthralgia, and these symptoms are detected in 14.4-44\% of cases. More rarely, acute myositis, myocarditis, purpura, livedoid skin lesions and rash have been reported. There are case reports presenting with neurological findings such as stroke, Guillain-Barre syndrome associated with great vascular involvement at a young age, which can also be confused with rheumatic disease findings. In Italy, Kawasaki-like disease has been reported 30 times more in the pre-COVID period. In addition, cytokine storm or secondary hemophagocytic lymphohistiocytosis is a condition with high mortality with ARDS and multi-organ failure, which may occur approximately 8-9 days after the onset of COVID-19 symptoms. In addition, it has been reported that antinuclear antibody (ANA) and antiphospholipid antibodies can be found positive in relation to COVID-19 (12). In a study conducted in 306 patients proved to be COVID-19, arthralgia and myalgia were detected in $26.4 \%$ of the patients, and no arthritis was detected during admission. However, 4 patients $(1.3 \%)$ developed acute arthritis after hospitalization, and it was observed that ankle, knee and foot metatars were mostly affected. Crystal arthritis was found in the synovial fluid examination of these 4 patients (13). In addition, COVID-19-associated reactive arthritis and acute arthritis with oligoarthritis have been reported as a rare presentation $(14,15)$.

COVID-19 Immunopathogenesis and Cytokine Storm Cytokine storm with thrombotic complications and disseminated intravascular coagulation (DIC) is the reason for this and is also known as macrophage activation 
syndrome (MAS). Genetic factors, malignancies such as lymphoma and especially viral infections are among the diseases that play a role in MAS etiology. After entering the respiratory system, it is thought that it enters the cell by binding to angiotensin converting enzyme-2 (ACE-2) receptors in the host tissue with its COVID-19 glycoprotein components. Here it replicates and spreads to other cells by breaking down the cell. It enables the immune system to be activated by recognizing the immune system viral antigens to MHC antigens and acquired immune system cells such as Natural Killer (NK) and acquired immune system cells such as cytotoxic T cells. Thus, proinflammatory cytokines and chemokines are released into the environment. In some patients, when their production is uncontrolled and large, a so-called cytokine storm occurs (16). In a study from China investigating mortality associated with COVID-19, it was found that D-Dimer increase, ferritin increase, lymphopenia, LDH increase and Troponin increase were associated with high mortality in relation to the hyperinflammatory response (17).

Interferon (IFN) response, which has an important role in eliminating viral infections, is thought to play a role in COVID-19 related cytokine storm. In particular, the Type 1 IFN response has been shown to be weaker and unstable here than other viral infections, and as a result, more proinflammatory cytokines and chemokines are released into the environment (18). An intense inflammatory response occurs by causing more stimulation of cells such as macrophage and granulocyte, such as tissue damage, and exaggerated production of IL-1, IL-6, TNF- $\alpha$, IL- 8 in patients with high viral load. It is suggested that anticytokine treatments to be used in the treatment of hyperinflammatory response associated with cytokine storm against excessive cytokines such as IL-6 may be useful here (19). Apart from the delayed Type 1 IFN response in the hyperinflammatory response, there are many mediators such as NF-kB, inflamazone mediated inflammation, cellular immunity components. It may also play a role in cytokine storm in different mechanisms, such as increased neutrophil extracellular traps (NETs). Finally, after the decrease in viral load in patients who developed ARDS, a gradually increasing hyperinflammation appears as a typical course $(16,20)$.

\section{COVID-19 Prognosis and Treatment Management in Inflammatory Rheumatic Patients}

There are contradictory publications regarding the prognosis of rheumatic diseases during the COVID-19 pandemic period, thus more evidence is needed. Although some studies have reported that the prognosis of rheumatic patients who have caught COVID-19 has not changed, there are publications advocating otherwise. In addition, regardless of primary rheumatic disease, older age, corticosteroid use and dosage, other immunosuppressive drugs and comorbidities accompanying it are thought to affect the prognosis $(21,22)$. Another situation may be that the use of chronic conventional disease modifying drugs (cDMARD) may mask severe symptoms of COVID-19, especially in elderly patients, which may delay the diagnosis of COVID-19 (23). Another interesting view is whether the risk of developing severe symptoms is lower when rheumatic patients receiving immunosuppressive therapy are infected with COVID-19. It has been suggested that drugs such as HCQ and tocilizumab (anti IL-6 blocker) can prevent this by preventing the hyperinflammatory state (24). In addition, the hypothesis that autoimmune diseases such as RA and SLE may be triggered by COVID-19 infection and that these diseases may increase after pandemic is another situation to be considered in the coming period (25).

General opinion is that patients who have chronic inflammatory rheumatic disease and who use drugs should not stop their medication and continue treatment unless they are infected with COVID-19. Both the EULAR and the American Rheumatology Association; American College of Rheumatology (ACR) reported that the published guidelines should be updated with the emergence of new data. Here, it is recommended that treatment should not be discontinued on condition of complying with hygiene conditions. It has been suggested to take measures to ensure that patients go to health centers less, to use telemedicine methods, to reduce the frequency of follow-up as much as possible and to open the dose intervals between intravenous treatments. Glucocorticoids should be used at the lowest possible dose but not stopped suddenly. In patients with stable rheumatic disease, cDMARDs such as metotrexate, sulfasalazine, leflunomide and quinine, and immunosuppressors such as mycophenolate mofetil, azathioprine, JAK inhibitors and biological agents can be used. Immunosuppressant dosage should not be reduced in those with rheumatic disease threatening vital organs. After COVID-19 exposure, HCQ, sulfasalazine and nonsteroidal anti-inflammatory drugs (NSAID) can be continued. Apart from this, cDMARD, biological agents and other immunosuppressants should be temporarily discontinued. IL-6 blockers can be continued in certain situations by making a joint decision. Although the level of evidence is weak in those with severe respiratory symptoms, NSAIDs should not be given $(5,26)$. Rituximab anti-CD20 antibody is used in various indications such as RA, SLE and Wegener granulomatosis in rheumatology practice and shows its effect by decreasing B cells. Rituximab is generally recommended not to be used or used with caution because it increases the risk of COVID-19 or may increase the severity of infection $(27,28)$.

\section{ANTI-RHEUMATIC DRUGS USED IN THE TREATMENT OF COVID-19}

Hydroxychloroquine (HCQ) / Chloroquine (CQ)

Among the anti-rheumatic drugs, quinine is one of the most discussed drugs for COVID-19. In the COVID-19 pandemic, especially among biological drugs, it was an inaccessible drug because HCQ entered the COVID-19 treatment protocols at a time when the continuity was decreased (29). These antimalarial drugs used in rheumatology due to their immunomodulatory effects are thought to prevent in-vitro virus replication in COVID-19, thus reducing viral load, and they may be effective in pneumonia and cytokine storm (30). However, there are publications that say otherwise. In a study from Italy, they showed that patients who previously used HCQ due to rheumatic disease were similar to those who did not use it due to COVID-19, and that the use of prophylactic quinine did not prevent infection (31). Although it is the first drug used in the treatment of COVID-19, it is controversial whether quinine is effective in the treatment of COVID19, and randomized controlled studies are needed (32). 


\section{IL-6 Blockers}

IL-6 is one of the proinflammatory cytokines involved in COVID-19 associated MAS and cytokine storm. It has been shown that the use of IL-6 blockers such as tocilizumab in early period may be effective in the treatment of COVID-19 pneumonia and respiratory failure, and it can decrease the serum levels of ferritin and fibrinogen, which are markers of hyperinflammatory status. Here, optimizing the time to start the drug is considered an important factor in the success of treatment (33).

\section{IL-1 Blockers}

It is thought that IL-1 blockers may have potential benefits especially in viral pneumonia associated with hyperinflammatory status in the treatment of COVID-19. IL-1 is one of the major proinflammatory cytokines that play a dominant role in cytokine storm. Anakinra is a recombinant IL-1R antagonist, and high-dose intravenous anakinra therapy is thought to be effective and safe in COVID-19 pneumonia (34).

\section{Other Medicines}

JAK inhibitors such as low-dose steroids, NSAID, TNF $\alpha$ inhibitors, Baricitinib are drugs that are thought to be theoretically effective in suppressing inflammation associated with COVID-19 but without strong clinical evidence (35). Intravenous Immunoglobulin (IVIG) may be effective in preventing inflammation and protecting against superinfections before ARDS develops (36).

\section{CONCLUSION}

In severe COVID-19, an aggressive inflammatory response with excessive immune activity is observed although the exact mechanisms are not known exactly. Especially the disruption in the innate immune system and increased proinflammatory cytokines in the environment eventually lead to cytokine storm and ARDS. When the hyperinflammatory state triggered by this viral infection is detected early, it offers us a 'window of opportunity' in lung involvement with anti-cytokine treatments. Successful results have been reported here with tocilizumab, the IL- 6 blocker. HCQ is an agent expected to be effective by reducing the viral load. It has been used in cytokine storm and mild-to-moderate COVID-19 cases, but it is in a position that is discussed and requires additional studies due to its low effectiveness in prophylaxis and treatment. Although corticosteroids, one of the frequently used drugs in rheumatology practice, are known to be effective in suppressing inflammation, they are associated with increased mortality in COVID-19 disease and should be used at the lowest possible dose. On the other hand, the risk of catching COVID-19 and death in inflammatory rheumatic diseases seems to be similar to the general population. It is generally recommended that anti-rheumatic drugs, including biological drugs, should not be discontinued during the COVID-19 pandemic unless the patients are infected with the virus. However, with the emergence of new data, the guides will be updated again.

Conflict of Interest: None declared by the authors.

Financial Disclosure: None declared by the authors.

Acknowledgements: None declared by the authors.

\section{REFERENCES}

1. Ge H, Wang X, Yuan X, Xiao G, Wang C, Deng T, et al. The epidemiology and clinical information about COVID-19. Eur J Clin Microbiol Infect Dis. 2020;39(6):1011-9.

2. Schett G, Manger B, Simon D, Caporali R. COVID-19 revisiting inflammatory pathways of arthritis. Nat Rev Rheumatol. 2020:16(8):465-70.

3. Weiss P, Murdoch DR. Clinical course and mortality risk of severe COVID-19. Lancet. 2020;395(10229):1014-5.

4. Pope JE. What does the COVID-19 pandemic mean for rheumatology patients? Curr Treatm Opt Rheumatol. 2020; [Epub ahead of print]. doi: 10.1007/s40674-02000145-y.

5. Landewé RB, Machado PM, Kroon F, Biljsma HW, Burmester GR, Carmona L, et al. EULAR provisional recommendations for the management of rheumatic and musculoskeletal diseases in context of SARSCoV-2. Ann Rheum Dis. 2020;79(7):851-8.

6. Zhou D, Dai SM, Tong Q. COVID-19: a recommendation to examine the effect of hydroxychloroquine in preventing infection and progression. J Antimicrob Chemother. 2020;75(7):1667-70.

7. Misra DP, Agarwal V, Gasparyan AY, Zimba O. Rheumatologists' perspective on coronavirus disease 19 (COVID-19) and potential therapeutic targets. Clin Rheumatol. 2020;39(7):2055-62.

8. Figueroa-Parra G, Aguirre-Garcia GM, GambaoAlonso CM, Camacho-Ortiz A, Galarza-Delgado DA. Are my patients with rheumatic diseases at higher risk of COVID-19? Ann Rheum Dis. 2020;79(6):839-40.

9. Pablos JL, Abasolo L, Alvaro-Gracia JM, Blanco FJ, Blanco R, Castrejón I, et al. Prevalence of hospital PCR-confirmed COVID-19 cases in patients with chronic inflammatory and autoimmune rhemuatic diseases. Ann Rheum Dis. 2020;79(9):1170-3.

10. Michelena X, Borrell H, López-Corbeto M, LópezLasanta M, Moreno E, Pascual-Pastor M, et al. Incidence of COVID-19 in a cohort of adult and paediatric patients with rheumatic diseases treated with targeted biologic and synthetic diseases-modifying anti-rheumatic drugs. Semin Arthritis Rheum. 2020;50(4):564-70.

11. Quartuccio L, Valent F, Pasut E, Tascini C, De Vita S. Prevalence of COVID-19 among patients with chronic inflammatory rheumatic diseases treated with biologic agents or small molecules: A population-based study in the first two months of COVID-19 outbreak in Italy. Joint Bone Spine. 2020;87(5):439-43.

12. Shah S, Danda D, Kavadichanda C, Das S, Adarsh MB, Negi VS. Autoimmune and rheumatic musculoskeletal diseases as a consequence of SARS-CoV-2 infection and its treatment. Rheumatol Int. 2020;40(10):1539-54.

13. López-González MD, Peral-Garrido ML, Calabuig I, Tovar-Sugrañes E, Jovani V, Bernabeu P, et al. Case series of acute arthritis during COVID-19 admission. Ann Rheum Dis. 2020; [Epub ahead of print]. doi: 10.1136/annrheumdis-2020-217914.

14. Saricaoglu EM, Hasanoglu I, Guner R. The first reactive arthritis case associated with COVID-19. J Med Virol. 2020; [Epub ahead of print]. doi: $10.1002 / j m v .26296$. 
15. Yokogawa N, Minematsu N, Katano H, Suzuki T. Case of acute arthritis following SARS-CoV-2 infection. Ann Rheum Dis. 2020; [Epub ahead of print]. doi: 10.1136/annrheumdis-2020-218281.

16. Soy M, Keser G, Atagündüz P, Tabak F, Atagündüz I, Kayhan S. Cytokine storm in COVID-19: pathogenesis and overview of anti-inflammatory agents used in treatment. Clin Rheumatol. 2020;39(7):2085-94.

17. Zhou F, Yu T, Du R, Fan G, Liu Y, Liu Z, et al. Clinical course and risk factors for mortality of adult inpatients with COVID-19 in Wuhan, China: a retrospective cohort study. Lancet. 2020;395(10229):1054-62.

18. Blanco- Melo D, Nilsson-Payant BE, Liu WC, Uhl S, Hoagland D, Møller R, et al. Imbalanced host response to SARS-CoV-2 drives development of COVID 19. Cell. 2020;181(5):1036-45.

19. Tufan A, Avanoğlu Güler A, Matucci-Cerinic M. COVID-19, immune system response, hyperinflammation and repurposing antirheumatic drugs. Turk J Med Sci. 2020;50(SI-1):620-32.

20. Siddiqi HK, Mehra MR. COVID-19 illness in native and immunsuppressed states: A clinical-therapeutic stating proposal. J Heart Lung Transplant. 2020;39(5):405-7.

21. Joavani V, Calabuig I, Peral-Garrido ML, TovarSugrañes E, López-González MD, Bernabeu P, et al. Incidence of severe COVID-19 in a Spanish cohort of 1037 patients with rheumatic diseases treated with biologics and JAK-inhibitors. Ann Rheum Dis. 2020; [Epub ahead of print]. doi: 10.1136/annrheumdis-2020-218152.

22. D'Silva KM, Serling-Boyd N, Wallwork R, Hsu T, Sparks JA, Wallace ZS. Response to: 'Incidence of severe COVID-19 in a Spanish cohort of 1037 patients with rheumatic diseases treated with biologics and JAK-inhibitors' by Jovani et al. Ann Rheum Dis. 2020; [Epub ahead of print]. doi: 10.1136/annrheumdis-2020-218179.

23. Sangelli C, Gentile V, Tirri R, Macera M, Cappabianca $\mathrm{S}$, Ciccia $\mathrm{F}$, et al. Chronic conventional diseasemodifying anti-rheumatic drugs masking severe SARS-CoV-2 manifestations in an elderly rheumatic patient. J Infect. 2020; [Epub ahead of print]. doi: 10.1016/j.jinf.2020.05.043.

24. Vakil-Gilani K, O'Rourke K. Are patients with rheumatologic diseases on chronic immunosuppressive therapy at lower risk of developing severe symptoms when infected with COVID-19? Clin Rheumatol. 2020;39(7):2067-8.

25. Gao ZW, Wang X, Lin F, Dong K. The correlation between SARS-CoV-2 infection and rheumatic diseases. Autoimmun Rev. 2020;19(7):102557.

26. Mikuls TR, Johnson SR, Fraenkel L, Arasaratnam JR, Baden LR, Bermas BL, et al. American College of Rheumatology Guidance for the management of rheumatic disease in adult patients during the COVID19 pandemic: version 1. Arhtritis Rheumatol. 2020; [Epub ahead of print]. doi: 10.1002/art.41301.

27. Avouac J, Airó P, Carlier N, Matucci-Cerinic M, Allanore Y. Severe COVID-19-associated pneumonia in 3 patients with systemic sclerosis treated with rituximab. Ann Rheum Dis. 2020; [Epub ahead of print]. doi: 10.1136/annrheumdis-2020-217864.

28. Sharmeen S, Elghawy A, Zarlasht F, Yao Q. COVID19 in rheumatic disease patients on immunsuppressive agents. Semin Arthritis Rheum. 2020;50(4):680-6.

29. Fragoulis GE, Evangelatos G, Arida A, Bournia VK, Fragiadaki K, Karamanakos A, et al. Treatment adherence of patients with systemic rheumatic diseases in COVID-19 pandemic. Ann Rheum Dis. 2020;[Epub ahead of print]. doi: 10.1136/annrheumdis-2020-217935.

30. Georgiev T. Coronavirus disease 2019 (COVID-19) and anti-rheumatic drugs. Rheumatol Int. 2020;40(5):825-6.

31. Favalli EG, De Lucia O, Biggioggero M, Del Papa N, Caporali R. Role of antimalarials in COVID-19: observational data from a cohort of rheumatic patients. Ann Rheum Dis. 2020; [Epub ahead of print]. doi: 10.1136/annrheumdis-2020-218068.

32. Ferner RE, Aronson JK. Chloroquine and hydroxychloroquine in COVID-19. BMJ. 2020;369:m1432. doi: 10.1136/bmj.m1432.

33. Toniati P, Piva S, Cattalini M, Garrafa E, Regola F, Castelli F, et al. Tocilizumab for the treatment of severe COVID-19 pneumonia with hyperinflammatory syndrome and acute respiratory failure: A single center study of 100 patients in Brescia, Italy. Autoimmun Rev. 2020;19(7):102568.

34. Pontali E, Volpi S, Antonucci G, Castellaneta M, Buzzi D, Tricerri F, et al. Safety and efficacy of early highdose IV anakinra in severe COVID-19 lung disease. J Allergy Clin Immunol. 2020;146(1):213-5.

35. Russell B, Moss C, George G, Santaolalla A, Cope A, Papa S, et al. Associations between immunesuppressive and stimulating drugs and novel COVID19-a systematic review of current evidence. Ecancermedicalscience. 2020;14:1022.

36. Prete M, Favoino E, Catacchio G, Racanelli V, Perosa F. SARS-CoV-2 infection complicated by inflammatory syndrome. Could high-dose human immunoglobulin for intravenous use (IVIG) be beneficial? Autoimmun Rev. 2020;19(7):102559. 